\section{Introduction to Topologies of Digital Work}

\author{
Mascha Will-Zocholl and Caroline Roth-Ebner
}

At the turn of the millennium, a "spatial turn" (Crang \& Thrift, 2000; Gunn, 2001) appeared, first in cultural studies and then increasingly in the social sciences, which triggered a controversial discussion, especially in the exchange with geography. The debate focused on whether the reflection about space as a category of analysis was really a new phenomenon or whether the previous historical development had hitherto been neglected in scientific debates: from oblivion of space to obsession of space. Progressive globalisation has also contributed to the spatial turn, and new concepts have increasingly been sought to describe new spatial relations and their consequences (Warf \& Arias,

M. Will-Zocholl ( $\varangle)$

Hessian University of Police and Administration, Wiesbaden, Germany e-mail: Mascha.Will-Zocholl@hfpv-hessen.de

C. Roth-Ebner

University of Klagenfurt, Klagenfurt, Austria

e-mail: Caroline.Roth@aau.at 
2009 , pp. 5f.). From today's perspective, it can be said that the reinvention of space as a category of analysis has led to a renewed focus on spatial issues. On this basis, we pursue spatial constellations, references and structures using the concept of "topologies". The term topology ${ }^{1}$ refers to a rethinking of space as a relational phenomenon that emerges and can be changed through social practice. Spatial references are always created, shapeable and artificial in this sense. They are produced and experienced (Brenneis et al., 2018; Lefebvre 1974/1991; Massey, 2005).

Technological innovations have always had an impact on the perception of space. Wolfgang Schivelbusch (1977), for example, describes how the invention of the railroad and its establishment as a means of transport in the early nineteenth century led to a shrinking of the natural world (Schivelbusch, 1977, p. 16), because distances could be covered in a much shorter time by rail and the spaces between two places seemed to disappear (ibid., p. 39). During the past decades, the increasing spread and use of modern information and communication technologies (ICTs) in tandem with the general neoliberal capitalist paradigm have enabled a new dimension of "time-space compression", as diagnosed by Harvey as early as 1989. With the spread of the Internet, it became possible to communicate and cooperate worldwide in real time from different locations. And this to a much greater extent than telephony or telephony-based services such as teletext had made possible. ICTs include traditional communication technologies such as telephone, radio and $\mathrm{TV}$, but most often refer to more recent communication technologies like computer soft- and hardware, mobile devices and the Internet. The use of ICTs has led to a multiplication of possibilities in our everyday lives, affecting the way people communicate, connect to each other, spend their leisure time, and work. In this anthology, the term digital media is used as well. It reflects the development of the past decades which entails that ever more of those ICTs are digital communication technologies which provide machine-readable communication in the form of videos, audio files, text and graphic messages. 


\section{Digitalisation, Informatisation and Mediatisation}

Digital media are at the centre of the current digitalisation discourse. While the term digitisation refers to the computer-based transformation of communication and information into a digital mode, digitalisation is understood as the social transformation wrought by the establishment and ubiquitous use of ICTs respectively digital media (Brennen \& Kreiss, 2016, n.p.). Digitalisation is a comprehensive social process that can be theoretically grasped in sociology as a new phase in "informatisation" (Boes \& Kämpf, 2007; Schmiede, 2006) or in media and communications as a new push in "mediatisation" (Krotz, 2003, p. 173). The theory of informatisation describes the implementation of an information layer to manage and control working processes based on a "conscious, systematic handling of information, especially including the generation and use of information and information systems" (Boes \& Kämpf, 2007, p. 197). The concept of mediatisation places emphasis on how the use of media changes the way we communicate, the way we construct our realities and hence, our culture, our social life and our work (Krotz, 2009, pp. 24, 31). Yet, this is not a unidirectional process, but a complex reciprocal relationship between societal and technological transformations.

Digitalisation is acting as a pivotal moment of profound change in workforce and labour, realigning value creation processes, business models, customer relations, work processes and-as taken up in this anthology - spatial relations of and in work.

Digitalisation processes are closely linked to those of virtualisation and the question of constructing reality. Manuel Castells identifies the emergence of "real virtuality" (Castells, 1996, pp. 367ff.) on the basis of electronic communication. These virtualities are not real in appearance, but real in their consequences. This notion can also be transferred to digitised and virtual work. We understand digitised work as work that is based on digital data and that processes them in some way. The core elements of digitised work are digital work tools (software applications), digital work objects (such as plans, graphics, text, calculations, videos, etc.), but also corresponding hardware that serves as an intermediary. Digitised work enables cooperation and monitoring as well as the 
storage, provision, integration or delivery of the work using digital ICTs. This also includes simulations of physical properties or complex scenarios of future developments. The term virtual work is often used synonymously with digital work or very broadly to describe a bundle of new developments of work, for example platform work or invisible labour (for an overview see Holts, 2018, p. 6f.). In this volume, virtual work refers to work and collaboration in virtual spaces from distributed places, that is, the disjunction of presence in a physical location and workspace. It has the form of information and communication streams which are processed and transported in computer networks (mostly Internet and Intranet; Roth-Ebner, 2015, p. 48).

Digitalisation and a worldwide ICT infrastructure in the form of the Internet also affect the perception of spatial references as well as the significance of places and can be seen as a basis for the emergence of "information space" (Baukrowitz \& Boes, 1996). This information space is a space of opportunities, a "new sphere of social action" that enables the saving, handling or exchanging of information and information objects and furthermore interacting with others and building relationships based on the Internet (Boes et al., 2017, p. 156). The latter marks a difference from earlier information systems, which were prestructured and limited to human-machine action. In contrast to this, the information space is vivid, open for all kinds of topics and spheres of life and for interaction between human beings (ibid., p. 156f.). With regard to work, it offers new possibilities for the organisation and division of labour, for collaboration and a "new degree of use of mental productive forces" (ibid., p. 158) leading to innovations promoting transparency, but also to new forms of control.

Information space theory further refers to the changing materiality of workplaces in the course of digitalisation and the advancing use of technologies and especially to the emergence of new working spaces. This approach emphasises the matter of space as well as the challenges of the parallel existence of virtual spaces and of places where people work (Will-Zocholl, 2021). Over the past decades, the topologies of work have changed substantially. This manifests in an internationalisation of the division of labour no longer limited to the production sector, the creation of new value chains and business models in terms of outsourcing, 
near- and offshoring as well as in new labour markets (crowd sourcing, cloud working, platform work). Work is organised more flexibly and can be delocalised. Cooperation over distance with locally and globally distributed (team) mates has become normal. This counts particularly for the fields of knowledge and creative work. In these areas, and for a long time, work was considered to be embedded in local milieus of (creative) knowledge exchange. Further, this kind of work was able to escape the logic of reorganisation and rationalisation. Nowadays, even creative and knowledge workers are affected by consequences of those new topologies of work (e.g., Boes et al., 2017; Gill et al., 2019; Pfeiffer et al., 2016; Pitts, 2016; Schmiede \& Will-Zocholl, 2011; Schörpf et al., 2017). During the time when the contributions to this anthology were being written, the relevance of virtual work increased dramatically. Due to the Covid-19 pandemic, people from all over the world had to stay at home and work from there in order to avoid infection, being connected via video conferencing and other computer-supported collaborative work tools. While before the Covid-19 pandemic, working from one's home was practised by only a small group of employees, around one in ten occasionally in 2019 (Sostero et al., 2020, p. 8), the share of workers performing their tasks at home at least some of the time increased to nearly half of the employees in Europe during the pandemic (Eurofound, 2020, p. 31). Assuming that most of this work was performed using ICTs, this is evidence for the thesis mentioned before, namely that social and technological changes are in constant interaction.

\section{Rethinking Places and Spaces of Work}

While the term place refers to clearly definable, geographically physical places, the concept of space is broader and also includes constructions that have no concrete reference to measurable points (Rothe \& Schade, 2009 , p. 195). This includes workspaces that emerge through the interaction and cooperation of people working together based on the Internet. They can be located in one place, for example, in the office, but also at different places, meeting virtually in the so-called information space. Along with the use of ICTs respectively digital media, workplaces change. 
They extend to virtual spaces, they multiply (e.g., when working while commuting or travelling, in co-working spaces, in the home office, etc.) and even overlap, in the case of acting in different virtual spaces simultaneously and being co-present in a physical surrounding.

The term topologies of work focuses on those spatial reconfiguration processes. It refers to the importance of places and takes into account our thesis that places themselves change and multiply, but do not become meaningless. Hence the detachment of social spatial references from geographical spatial references for example, by no longer requiring the co-presence of team mates in one place for working activities, cannot be equated with the irrelevance of geographies (Will-Zocholl et al., 2019). Moreover, "placelessness" must be actively produced if a delocalisation of work is intended, as Jörg Flecker and Annika Schönauer (2016) showed with their study on digital service work in global value chains.

The debate about topologies of work emphasises that the changes of spatial references also extend beyond new geographical orders. This includes the reorganisation of the division of labour and the relocation of work to other places or regions as well as the emergence of virtual structures that are linked to the emergence of the information space.

This gives rise to a lively debate on the relationship and role of places and spaces, which is also reflected in the increasing number of publications on this topic. Some focus on the individual level of workplaces and their conditions as well as on employee identity (e.g., Anandarajan et al., 2006; Huws \& Dahlmann, 2010; Lehdonvirta, 2016; Roth-Ebner, 2016; von Streit, 2011; Webster \& Randle, 2016), others on the organisation and the design of new workplaces (e.g., Coles Levine \& Johnson Sanquist, 2016; Miller \& Marsh, 2014; Schittich, 2012). At a meso level, spatial reconfigurations in organisations are taken into account, especially in connection with questions of materiality (e.g., Carlile et al., 2013; Dale \& Burell 2007; Leonardi et al., 2012; van Marrewijk \& Yanow, 2010). On a macro level, the spatial reorganisation of work in a larger context is at the centre of scholarly focus: changing value chains, the information space and the international division of labour (e.g., contributions in Briken et al., 2017; Flecker, 2016; Newsome et al., 2015; further Holtgrewe, 2014; Huws, 2006). Only a few negotiate the triangle of space, place and work on a conceptual level (Boes \& Kämpf, 
2007; Boes et al., 2017; Flecker \& Schönauer, 2016; Gill et al., 2019; Roth-Ebner, 2016; Will-Zocholl, 2016).

The Dynamics of Virtual Work series has been and still is an appropriate place to address the relationship of work, digitalisation and space. Hence, this volume aims at broadening the basis of topological research, taking into account the current developments of the digital transformation, theoretical considerations and empirical evidence. It investigates the topologies of digital work by addressing the following questions:

1. How relevant is the local embeddedness of work? To what extent does place matter in the context of a digitised world of work and what does this mean for the division of labour (national-international, but also urban-rural)?

2. What are the consequences of the digitalisation of work for previous concepts of geographical places, workplaces and workspaces?

3. How are those who work located in the digitised world of work? What subjective capacities do they need to cope with these changing working conditions?

These questions are reflected in three book Parts, taking into account different spatial scales: from the geographies of work to places of work (and their conditions) to virtual workspaces.

\section{Brief Introduction to the Contributions}

This book developed from the session "Digital Working Spaces. New Geographies Evolving Shaped by Digitalization and Virtualization of Work," a session at the ISA World Forum 2016 held in Vienna, as well as from a call for papers for the anthology. ${ }^{2}$ The outcome is an international and interdisciplinary composition on the topologies of digital work. Country perspectives are taken into account, starting from Northern and Central Europe (Scandinavia, Austria), via Eastern Europe (Poland, Estonia, Russia) to Asia (China, Japan, Singapore). This promises particularly exciting insights, as different topics are considered from very different cultural, national and linguistic perspectives. 
As Brenneis et al., (2018, p. 11) emphasise, the analysis of topologies requires the participation of different disciplines. Thus, the contributions present interdisciplinary perspectives, above all from sociology, media and communications, political economy, working life science, management sciences, environmental psychology and communication history. The issues and questions addressed in the contributions are distributed across all levels of human life: the micro level of the individual, the meso level of organisations and the macro level of society and culture, representing the fact that questions of technological and spatial transformation involve our social reality at all levels of scale.

The three Parts of the book discuss different aspects of the abovementioned questions and along with this, working processes, conditions and the working environment. Taking a broader perspective, the development of new geographical arrangements in the division of labour, like the localisation, de- and relocalisation of work are addressed. In a narrow sense, light is shed on the way workplaces change from relatively stable local and physical environments ("office") to mobile and interchangeable places (café, beach, car, etc.). The physical offices themselves are expanded by means of the information space in the form of chat rooms or ticketing systems supporting team work (OneNote or Basecamp for example), with spatial consequences for the people working. In fact, the categorisation into three Parts does not represent a clear distinction of issues and phenomena, since they overlap. Yet, they might serve as a useful structuring aid for the readers of this volume. It should be noted that addressing "work" in this volume mainly refers to gainful employment or professional work. The only exception is the contribution of Jian Lin with its focus on social media work, which may be paid or unpaid. Yet, the boundaries between the two poles are blurring in times of "prosumer" culture (Thakur Varma \& Devi Mishra, 2020), where consumers of media simultaneously act as producers thereof.

\subsection{Part I: Geographies of Digital Work}

Part I deals with the geographies of digital work, focusing on shifts and new formations of economic spatial relations in different areas of the 
globalised world. In their contribution, Andrey Shevchuk, Denis Strebkov and Alexey Tyulyupo shed light on the geography of the digital freelance economy in Russia and beyond that on a global scale. Using data from a Russian-language online labour platform (reaching fourteen years into the past), they determine a distinct online labour market based on the Russian language, which functions across the territory of the former Soviet Union and goes even further to extend around the globe. They observe the creation of a new spatial division of labour through virtual migration, leading to the decentralisation of the labour market, while showing that place still matters in times of the digitised world of work.

A concrete form of digital labour is dealt with in Anna Ozimek's contribution, where she investigates the global digital games industry and its outsourcing practices in the Central and Eastern Europe (CEE) region. Drawing on data from two research projects, involving an interview study with people engaged in the digital games industry, as well as analyses of secondary sources, she demonstrates that, on the one hand, games can be understood as a "global medium" that can be produced "everywhere". On the other hand, reasons stated for outsourcing software development to Poland and Estonia document the continuing significance of the local embeddedness of the digital games workforce.

The contribution by Brett Neilson and Ned Rossiter refers to Asia, but describes an extremely globalised issue. The authors analyse automating labour and the spatial politics of data centre technologies. Focusing on Singapore, a growth hub for data infrastructure, they depict data centres as automated environments that foster automation in workplaces across regional and global scales. In a project entitled "Data Farms: Circuits, Labor, Territory", they established that data centres act not just as technical infrastructures, but also as political institutions, which imply power shifts across vast territories and transform geopolitical patterns, hence they contribute to a transformation of digital capitalism. 


\subsection{Part II: Places of Work}

Part II focuses on the places where work is done, as place does matter and has to be taken into consideration. In the first contribution in this section, Christian Oggolder applies a historical perspective to workplaces and production environments and contrasts work in the current digitalised environment with modern as well as premodern forms of work. By introducing typical places for each period-the house for the premodern era, the city for the modern and the network for late modern times - the author maintains that the modern separation of work and private life is a construction based on societal and economic demands. He interprets the digitally enabled flexible time and spatial arrangements of the current world of work as a reference back to premodern patterns of work.

Jian Lin's contribution explores the spatial production of China's entertaining social media industry, called "wanghong". Conducting a political-economic analysis and based on interviews with wanghong creators, Multi-Channel Network entrepreneurs and managers of platform companies as well as the study of secondary media reports, he observes networking effects that transform the local place into a space of flows. Individuals, participating in these communities both as creators and audience, gather together in the virtual space or in the cloud from disparate locations. The author describes this development as a transformation of various local places into mediaspaces by the economy's dissolving and expanding beyond spatial segregation and the urbanmoulded popular culture.

Remaining in the Asian region, Keita Matsushita explores the transformations in the perception of workplaces and styles by examining working in co-working spaces as well as the phenomenon of workationing (working while on vacation). Based on fieldwork in Japan, which included interviews with managers and users of co-working spaces as well as workationers, he observes a transformation from place-based workstyles to style-based workplaces, in both urban and rural areas. While co-working in the urban area reflects the trend of deofficisation and localisation, workationing in the rural area can be described as officisation and delocalisation. 


\subsection{Part III: Virtual Working Spaces}

Part III discusses emerging working spaces that are no longer connected to specific places and explores changes in work practices within the information space. Calle Rosengren, Ann Bergman, and Kristina Palm launch the section with their contribution on ICT-enforced boundary work, where they consider the weakening boundaries between work and private life due to the access to and use of ICT on the level of the individual. Applying a practice-based approach including time diaries and qualitative interviews, they explore the question of how ICT is used by employees to manage their availability for both private and professional life spheres. The data shows that rather than the question of being available or not, what is actually relevant for the individual's well-being is the feeling of being in control of one's boundary practices.

Delving deeper into the subject of blurring boundaries between work and private life, Dominik Klaus and Jörg Flecker address the interrelation of ICT-enabled boundaryless work and identity work drawing on the results of two case studies, where qualitative interviews were conducted in knowledge-intense business services. They ask for the ways in which the workers handle the blurring boundaries, deal with changing spatial resources, and the requisites for identity work. Continuing the argumentation of Calle Rosengren, Ann Bergman and Kristina Palm, to a certain extent, they emphasise that place, space and physical aspects of workplaces are important resources for the workers' identities, and when these spatial ties loosen in the course of teleworking, this poses both pillars for and threats to identity work.

The final contribution written by Ingrid Nappi and Gisele de Campos Ribeiro pays attention to the duality of the employee's interaction with physical and virtual worlds of work. Addressing the 2020 Covid-19 crisis as a trigger for teleworking, they conducted two online surveys with white-collar employees in France to find out more about the employees' attitude towards the virtual office. The first survey was run during a phase of lockdown, at a time when companies adopted virtual office practices as a crisis management tool. The second survey was conducted post-lockdown. Their results reveal (among others) that the participants missed their work routines, and face-to-face interaction with co-workers 
during the lockdown. Nevertheless, they would also like to continue their teleworking to varying degrees in the future.

\section{Notes}

1. Drawn from Greek tópos (place/location), topology literally means the "study of places" (Naylor and Sell 1982, p. 44). In various scientific disciplines, it is used to describe relationships between places of spatial structures (e.g., in biology, mathematics, but also in philosophy, linguistics and literature).

2. The entire proposal was reviewed by the series editors Ursula Huws and Rosalind Gill as well as the publisher. Moreover, the contributions of the book were subjected to a multistage peer review.

\section{References}

Anandarajan, M., Teo, T. S. H., \& Simmers, C. A. (Eds.). (2006). The internet and workplace transformation. Routledge.

Baukrowitz, A., \& Boes, A. (1996). Arbeit in der "Informationsgesellschaft“: Einige Überlegungen aus einer (fast schon) ungewohnten Perspektive. In R. Schmiede (Ed.), Virtuelle Arbeitswelten. Arbeit, Produktion und Subjekt in der "Informationsgesellschaft“ (pp. 129-158). edition sigma.

Boes, A., \& Kämpf, T. (2007). The nexus of informatisation and internationalisation: A new stage in the internationalisation of labour in globalised working environments. Work Organisation, Labour \& Globalisation, 1(2), 193-208.

Boes, A., Kämpf, T., Langes, B., \& Lühr, T. (2017). The disruptive power of digital transformation. In K. Briken, S. Chillas, M. Krzywdzinski, \& A. Marks (Eds.), The new digital workplace: How new technologies revolutionise work. Critical Perspectives on Work and Employment (pp. 53-175). Palgrave Macmillan.

Brenneis, A., Honer, O., Keesser, S., Ripper, A., \& Vetter-Schultheiß, S. (2018). Topologie der Technik: Manifestation eines interdisziplinären Forschungsprogramms. In A. Brenneis, O. Honer, S. Keesser, A. Ripper, 
\& S. Vetter-Schultheiß (Eds.), Technik - Macht - Raum: Das Topologische Manifest im Kontext interdisziplinärer Studien (pp. 1-35). Springer VS.

Brennen, J. S., \& Kreiss, D. (2016). Digitalization. Wiley Online Library. https://doi.org/10.1002/9781118766804.wbiect111. Accessed 17 February 2021.

Briken, K., Chillas, S., Krzywdzinski, M., \& Marks, A. (Eds.). (2017). The new digital workplace: How new technologies revolutionise work. Critical Perspectives on Work and Employment. Palgrave Macmillan.

Carlile, P. R., Nicolini, D., Langley, A., \& Tsoukas, H. (Eds.). (2013). How matter matters: Objects, artifacts, and materiality in organization studies. Oxford University Press.

Castells, M. (1996). The rise of the network society: The information age: Economy, society and culture. Blackwell.

Coles Levine, D., \& Johnson Sanquist, N. (Eds.) (2016). Work on the move 2: How social, leadership and technology innovations are transforming the workplace in the digital economy. IFMA Foundation.

Crang, M., \& Thrift, N. (Eds.). (2000). Thinking space. Routledge.

Dale, K., \& Burrell, G. (2007). The spaces of organisation and the organisation of space: Power, identity and materiality at work. Palgrave Macmillan.

Eurofound. (2020). Living, working and COVID-19 (COVID-19 series). Publications Office of the European Union.

Flecker, J. (Ed.). (2016). Space, place and global digital work. Palgrave Macmillan.

Flecker, J., \& Schönauer, A. (2016). The production of 'placelessness': Digital service work in global value chains. In J. Flecker (Ed.), Space, place and global digital work (pp. 11-30). Palgrave Macmillan.

Gill, R., Pratt, A. C., \& Virani, T. E. (Eds.). (2019). Creative hubs in question: Place, space and work in the creative economy. Palgrave Macmillan.

Gunn, S. (2001). The spatial turn: Changing histories of space and place. In S. Gunn \& R. J. Morris (Eds.), Identities in space: Contested terrains in the Western city since 1850 (pp. 1-14). Ashgate.

Harvey, D. (1989). The condition of postmodernity: An enquiry into the origins of cultural change. Blackwell.

Holtgrewe, U. (2014). New new technologies: The future and present of work in information and communication technology. New Technology, Work and Employment, 29, 9-24.

Holts, K. (2018). Understanding virtual work: Prospects for Estonia in the digital economy (Resource document). Riigikogu. https:/www.riigikogu.ee/ 
wpcms/wp-content/uploads/2017/09/Virtual-work-size-and-trends_final1. pdf. Accessed 21 February 2021.

Huws, U. (2006). The restructuring of global value chains and the creation of a cybertariat. In C. May (Ed.), Global corporate power. International Political Economy Yearbook (pp. 65-82). Lynne Rienner.

Huws, U., \& Dahlmann, S. (2010). Global restructuring of value chains and class issues. In N. J. Pupo \& M. P. Thomas (Eds.), Interrogation the new economy: Restructuring work in the 21st century (pp. 65-92). UTP.

Krotz, F. (2003). Die Mediatisierung der Lebensräume von Jugendlichen. Perspektiven für die Forschung. In J. Bug \& M. Karmasin (Eds.), Telekommunikation und Jugendkultur: Eine Einführung (pp. 167-183). Westdeutscher.

Krotz, F. (2009). Mediatization: A concept with which to grasp media and societal change. In K. Lundby (Ed.), Mediatization: Concept, changes, consequences (pp. 21-40). Peter Lang.

Lefebrve, H. (1974). La production de l'espace. Anthropos. English edition: Lefebrve, H. (1991). The production of space (D. Nicholson-Smith, Trans.). Blackwell.

Lehdonvirta, V. (2016). Algorithms that divide and unite: Delocalisation, identity and collective action in 'microwork.' In J. Flecker (Ed.), Space, place and global digital work (pp. 53-80). Palgrave Macmillan.

Leonardi, P. M., Nardi, B. A., \& Kallinikos, J. (Eds.). (2012). Materiality and organizing: Social interaction in a technological world. Oxford University Press.

Massey, D. (2005). For space. Sage.

Miller, P., \& Marsh, E. (2014). The renaissance of work: Delivering digital workplaces fit for the future. Gower.

Naylor, A. W., \& Sell, G. R. (1982). Linear operator theory in engineering and science. Applied Mathematical Sciences, 40. https://doi.org/10.1007/978-14612-5773-8_3

Newsome, K., Taylor, P., Bair, J., \& Rainnie, A. (Eds.). (2015). Putting labour in its place: Labour process analysis and global value chains. Critical Perspectives on Work and Employment. Palgrave Macmillan.

Pfeiffer, S., Wühr, D., \& Schütt, P. (2016). Virtual innovation work: Labour, creativity, and standardisation. In J. Webster \& K. Randle (Eds.), Virtual workers and the global labour market (pp. 77-93). Palgrave Macmillan.

Pitts, F. H. (2016). Rhythms of creativity and power in freelance creative work. In J. Webster \& K. Randle (Eds.), Virtual workers and the global labour market (pp. 139-159). Palgrave Macmillan. 
Roth-Ebner, C. (2015). Der effiziente Mensch: Zur Dynamik von Raum und Zeit in mediatisierten Arbeitswelten. transcript.

Roth-Ebner, C. (2016). Spatial phenomena of mediatised work. In J. Flecker (Ed.), Space, place and global digital work (pp. 227-245). Palgrave Macmillan.

Rothe, K., \& Schade, A.-K. (2009). Transnational, national, lokal. Protesträume im Internet. In I. Köster, \& K. Schubert (Eds.), Medien in Raum und Zeit: Maßverhältnisse des Medialen (pp. 193-221). transcript.

Schittich, C. (Ed.). (2012). In detail: Work environments: Spatial concepts, Usage strategies, communications. Institut für internationale ArchitekturDokumentation.

Schivelbusch, W. (1977). Geschichte der Eisenbahnreise: Zur Industrialisierung von Raum und Zeit im 19. Jahrhundert. Carl Hanser.

Schmiede, R. (2006). Knowledge, work and subject in informational capitalism. In J. Berleur, M. I. Nurminen, \& J. Impagliazzo (Eds.), Social informatics: An information society for all? In remembrance of Rob Kling: Proceedings of the Seventh International Conference on Human Choice and Computers (HCC7), IFIP TC 9, Maribor, Slovenia, September 21-23, 2006 (pp. 333-354). Springer Science and Business Media.

Schmiede, R., \& Will-Zocholl, M. (2011). Engineers' work on the move: Challenges in automotive engineering in a globalized world. Engineering Studies, 3, 101-121.

Schörpf, P., Flecker, J., Schönauer, A., \& Eichmann, H. (2017). Triangular love-hate: Management and control in creative crowdworking. New Technology, Work and Employment, 32, 43-58.

Sostero, M., Milasi, S., Hurley, J., Fernández-Macías, E, \& Bisello, M. (2020). Teleworkability and the COVID-19 crisis: A new digital divide? (JRC working paper series on labour, education and technology 2020/05). European Commission.

Thakur Varma, S., \& Devi Mishra, K. (2020). Media blogs in the prosumer culture: A study of social media narratives in Indian political communication. International Journal of Advanced Science and Technology, 29(9), 5920-5931.

Van Marrewijk, A. H., \& Yanow, D. (Eds.). (2010). Organizational spaces: Rematerializing the workaday world. Edward Elgar.

Von Streit, A. (2011). Entgrenzter Alltag - Arbeiten ohne Grenzen?: Das Internet und die raum-zeitlichen Organisationsstrategien von Wissensarbeitern. transcript. 
Warf, B., \& Arias, S. (2009). Introduction: The reinsertion of space in the humanities and social sciences. In B. Warf \& S. Arias (Eds.), The spatial turn: Interdisciplinary perspectives (pp. 1-10). Routledge.

Webster, J., \& Randle, K. (2016). Positioning virtual workers within space, time, and social dynamics. In J. Webster \& K. Randle (Eds.), Virtual workers and the global labour market (pp. 3-34). Palgrave Macmillan.

Will-Zocholl, M. (2016). New topologies of work: Informatisation, virtualisation, and globalisation in automotive engineering. In J. Flecker (Ed.), Space, place and global digital work (pp. 31-51). Palgrave Macmillan.

Will-Zocholl, M. (2021). Information space(s). In R. Appel-Meulenbroek \&

V. Danivska (Eds.), Workplace theories: A handbook of theories on designing alignment between people and the office environment (pp. 82-93). Routledge. Will-Zocholl, M., Flecker, J., \& Schörpf, P. (2019). Zur realen Virtualität von Arbeit. Raumbezüge in digitalisierter Wissensarbeit. AIS-Studien, 12(1), 3654.

Open Access This chapter is licensed under the terms of the Creative Commons Attribution 4.0 International License (http://creativecommons.org/ licenses/by/4.0/), which permits use, sharing, adaptation, distribution and reproduction in any medium or format, as long as you give appropriate credit to the original author(s) and the source, provide a link to the Creative Commons license and indicate if changes were made.

The images or other third party material in this chapter are included in the chapter's Creative Commons license, unless indicated otherwise in a credit line to the material. If material is not included in the chapter's Creative Commons license and your intended use is not permitted by statutory regulation or exceeds the permitted use, you will need to obtain permission directly from the copyright holder.

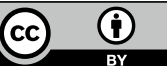

